\title{
Wheat Seed-Borne Mycoflora, Pathogenicity of Fusarium moniliforme Isolates and their Molecular Characterization
}

\author{
El-Wakil, D.A. \\ Agricultural Research Center, Plant Pathology Research Institute, Giza, Egypt. \\ Kingdom of Saudi Arabia, Jazan University, College of Science, Biology Department, P.O.Box:114
}

\begin{abstract}
Nine samples of wheat grains cv. Sakha 69, were screened for the associated fungi, 15 fungal species belonging to eight genera were isolated from wheat seeds. The isolated fungi were Aspergillus flavus, Aspergillus niger, Aspergillus ochraceous, Aspergillus parasiticus, Alternaria alternata, Stemphylium sp., Cladosporium sp., Drechslera sp. Fusarium solani, Fusarium moniliforme, Fusarium semitectum, Fusarium nivale, Fusarium oxysporum, Penicillium spp., Trichoderma sp. The genus Aspergillus gave the highest percentage of seed colonization of the isolated fungi followed by Fusarium spp. Pathogenicity test for nine isolates of F. moniliforme was conducted under greenhouse conditions to investigate the levels of infection against wheat cv. Sakah 69 and the percentage of infection was used as a criteria to evaluate the pathogenicity of $F$. moniliforme isolates against wheat seedlings. Cluster analysis was a reliable method to differentiate between nine isolates belonging to the genus Fusarium. Three different primers were used in the following study to differentiate among $F$. moniliforme isolates and the third primer proved to be the best in grouping $F$. moniliforme isolates into numerous distinct groups.
\end{abstract}

Key Words: Wheat (Triticum aestivum L.), seed-borne mycoflora, RAPD technique, pathogenicity of $F$. moniliforme.

\section{Introduction}

Numerous injuries and stresses, affect on wheat plants at all stages of growth, which interfere with their normal functioning and development. Each year wheat losses are increased due to seed infection and contamination [1] and [2].Therefore a seed health technique usually plays an important role for successful cultivation and yield exploitation of a crop species. From various factors that affect seed health, the most important are the seed borne fungi that lower seed germination and reduce seed vigor resulting in low yield and quality [3]. Earlier investigations reported that seed plays an important role not only for successful cultivation but also for increasing yield of crop. Numerous seed-borne pathogens of grain crops are responsible to cause variation in plant morphology and also reducing yield [4] and [5]. Fusarium sp. is one of the most important genera of plant pathogenic fungi, with a record of devastating infections in many different kinds of economically important plants [6]. Numerous crops all over the world are attacked by Fusarium spp. which are responsible for wilt blights, root rots and cankers. In recent years the use of various nucleic acid-based techniques for the detection and identification of microorganisms has dramatically increased and may provide high specific tools for molecular studies [7] and [8]. Restriction fragment length polymorphisms (RFLPS), which are costly and time consuming, can be used; however, the random amplified polymorphic DNA (RAPD) is also a suitable technique to evaluate taxonomic identity. The application of (RAPD) to produce isolatespecific DNA-finger prints is especially promising [8] and [9]. This technique has the advantage of that no DNA base sequence information of the organism is needed. The technical simplicity and speed of RAPD methodology is a principal advantage over other techniques [7].

The aim of the present study was to survey wheat seed-borne fungi, test the pathogenicity of some isolates against wheat cv. Sakha 69 and to compare the molecular characterization for these isolates by using RAPD technique.

\section{Source of seed samples and isolation}

\section{Materials and Methods}

Nine seed samples with a bad disease history of wheat cv. Sakah 69 were obtained from different locations in Egypt. A random subsample of 100 wheat seeds was surface sterilized in $2.5 \%$ Clorox solution for 2 minutes, and washed several times in sterilized water [10] and [11]. Twenty five sterilized wheat seeds of cv. Sakha 69 were randomly selected and placed on $8.5 \mathrm{~cm}$ Petri dishes on PDA medium, each was replicated 4 times; plates were incubated for 12 -hr darkness at $20 \pm 2^{\circ} \mathrm{C}$ for 7 days. After incubation each colony was examined macroscopically or microscopically for identification the genus or species level according to [12], [13] and [14]. Isolation frequency and percentage of infection was recorded and tabulated according [11]. 


\section{Pathogenicity test of nine $F$. moniliforme isolates against wheat grains}

Substrates for growth of each $F$. moniliforme isolate; previously isolated from wheat grains were prepared in $500 \mathrm{ml}$ glass bottles; each bottle contained $50 \mathrm{~g}$ of sorghum grains and $40 \mathrm{ml}$ of tap water. The bottles were autoclaved for 30 minutes. Isolate inocula, were taken from one-week-old culture on PDA were aseptically introduced into the bottles and allowed to colonize sorghum grains for 3 weeks. Batches of autoclaved clay loam soil were inoculated separately with inoculums of each isolate at the rate of $50 \mathrm{~g} / \mathrm{kg}$ of soil. Infested soil was dispended in $25 \mathrm{~cm}$-diameter clay pots and these were planted with 20 seeds per pot for apparently healthy; and the surface sterilized wheat grains cv. Sakha 69 to insure that the source of infection were only from the artificial inoculation with Fusarium moniliforme isolates. For control treatment sterilized sorghum grains were mixed thoroughly with soil at a rate of $50 \mathrm{~g} / \mathrm{kg}$ of soil. Pots were randomly distributed on a greenhouse bench under a temperature regime ranged from $20 \pm 2^{\circ} \mathrm{C}$ to $24 \pm 2^{\circ} \mathrm{C}$. Percentage of infection was recorded after 45 days of planting [15].

\section{Molecular Characterization}

\section{Extraction of genomic DNA of nine $F$. moniliforme isolates}

DNA was extracted from 50mg of mycelium from nine $F$. moniliforme isolates using Qiagen kit for DNA extraction. The extracted DNA was dissolved in $100 \mu \mathrm{l}$ of elution buffer. The concentration and purity of the obtained DNA was determined by using "Gen qunta" system-Pharmacia Bio-tech. The purity of the DNA for all samples was $90-70 \%$ based on the 1.6 and 1.8 ratio. The DNA concentration was adjusted at $6 \mathrm{ng} / \mu 1$ for all samples in TE buffer $\mathrm{pH} 8.0$.

\section{Random amplified polymorphic DNA (RAPD) technique}

RAPD amplification was carried out using three different random primers shown in Table ( 1 ) . Each $25 \mu 1$ reaction mixture contained 1 unit of Taq DNA polymerase, $0.2 \mathrm{mM}$ each dNTP,1xPCR buffer, $3 \mathrm{mM}$ $\mathrm{MgCl}_{2}, 10$ pmol of primer and approximately $50 \mathrm{ng}$ of template genomic DNA. PCR conditions was as follows: initial denaturation at $95^{\circ} \mathrm{C}$ for $5 \mathrm{~min}$, followed by 45 cycles of denaturation at $95^{\circ} \mathrm{C}$ for $1 \mathrm{~min}$, annealing at $36^{\circ} \mathrm{C}$ for $1 \mathrm{~min}$ and extension at $72^{\circ} \mathrm{C}$ for $2 \mathrm{~min}$ followed by a final extension cycle at $72^{\circ} \mathrm{C}$ for 10 min then held at $4^{\circ} \mathrm{C}$. The amplified products were separated on $2 \%$ agarose gel at 75 constant volt, using $1 \mathrm{x}$ TBE buffer followed by staining with ethidium bromide solution $(1 \mu \mathrm{g} / \mathrm{ml})$ and the bands were visualized with UV transilluminator. All gels were scanned for band $R_{f}$ using gel documentation system (AAB).The M.W. of bands were determined against DNA marker Ameresco (100bp)-k800 and phenograms were based on un weighted pair-group method of arithmetic means ( UPGMA).

Table (1): List of primers used for RAPD analysis in this study along with their sequences

\begin{tabular}{|l|c|}
\hline Primer Code : & Sequences (5'-------- $\mathbf{3}^{\prime}$ ) \\
\hline Primer -1 & CGTGCGGGAA \\
\hline Primer -2 & GTTT CGCTCC \\
\hline Primer -3 & GTAGACCCGT \\
\hline
\end{tabular}

\section{Statistical analysis}

The experimental design of pathogenicity test was a randomized complete block with replicates. Analysis of variance (ANOVA) of the data was performed with the Mstat-C package (A Micro-computer Program for the Design, Management, and Analysis of Agronomic Research Experiments, Michigan State Univ.,USA). Least significant difference (LSD) was used to compare means.

\section{Gel analysis of the data}

DNA gels were scanned for band $\mathrm{R}_{\mathrm{f}}$ using gel documentation system (AAB Advanced American Biotechnology 1166). The different M.W. of band was determined against PCR marker Ameresco (100bp)-k800 by unweighted pair-group method based on arithmetic mean (UPGMA).

\section{Results and Discussion}

A total of 15 fungal species belonging to eight fungal genera were isolated Table (2) from wheat grains cv. Sakha 69 and the most frequent fungus were Aspergillus sp., followed by Fusarium spp., whereas the lowest fungus was Trichoderma sp. also, isolation yielded different species of fungi. Sample no. 4 followed by sample no. 6 yielded the highest percentage of fungi, while the sample no. 3 and 8 yielded the lowest percentage of fungi. The other wheat samples yielded different percentages of fungi ranged from 15.1 to $18.5 \%$, respectively. The occurrence of pathogen species are of central importance in the ecology of host-pathogen interactions in a complex pathosystems, i.e., those with multiple pathogens in a single or multiple hosts. Within such pathosystems, biotic and abiotic factors influence the distribution and abundance of such pathogen species [16], 
[17] and [18]. Subsequently, patterns of association results from interrelationships among organisms and from environmental factors. Such these patterns depends on whether or not organisms selected or avoid the same habitat or have no interaction [14], [19], [20] and [21]. Therefore, pathogen species (e.g. seed-borne pathogens) were in a competition for a single resource (e.g., a seed) tends to occupy the same niche. Such niche overlap generates affinity (or lack affinity) for coexistence among species, known as inter specific associations [3].

Table (2): Isolation and frequency (\%) of fungi isolated from nine samples of wheat seeds cv. Sakha 69 on PDA medium.

\begin{tabular}{|c|c|c|c|c|c|c|c|c|c|}
\hline Fungi & $\begin{array}{c}{ }^{\mathrm{a}} \mathrm{S}-1 \\
\%\end{array}$ & $\begin{array}{c}\text { S-2 } \\
\%\end{array}$ & $\begin{array}{c}\text { S-3 } \\
\%\end{array}$ & $\begin{array}{c}\mathrm{S}-4 \\
\%\end{array}$ & $\begin{array}{c}\text { S-5 } \\
\%\end{array}$ & $\begin{array}{c}\text { S-6 } \\
\%\end{array}$ & $\begin{array}{c}\text { S-7 } \\
\%\end{array}$ & $\begin{array}{c}\mathbf{S}-8 \\
\%\end{array}$ & $\begin{array}{c}\text { S-9 } \\
\%\end{array}$ \\
\hline Aspergillus flavus & 16.9 & 13.9 & 15.9 & 14.1 & 12.2 & 15.7 & 7.0 & 22.6 & 9.5 \\
\hline Apergillus niger & 7.8 & 7.7 & 25.0 & 11.9 & 10.8 & 14.6 & 10.5 & 24.2 & 5.9 \\
\hline Aspergillus ochraceus & 9.1 & 15.4 & 0.0 & 9.8 & 4.0 & 13.5 & 11.6 & 21.0 & 13.1 \\
\hline Aspergillus parasiticus & 0.0 & 7.7 & 6.8 & 1.1 & 6.7 & 11.2 & 15.1 & 8.1 & 9.5 \\
\hline Alternaria alternata. & 0.0 & 0.0 & 4.5 & 2.2 & 8.1 & 8.9 & 7.0 & 0.0 & 7.1 \\
\hline Stemphylium sp. & 12.9 & 4.6 & 2.3 & 3.3 & 0.0 & 6.7 & 8.1 & 0.0 & 3.6 \\
\hline Cladosporium $\mathrm{sp}$. & 14.3 & 4.6 & 0.0 & 6.5 & 9.5 & 0.0 & 4.6 & 0.0 & 8.3 \\
\hline Drechslera sp. & 15.6 & 16.9 & 9.0 & 5.4 & 0.0 & 7.8 & 1.2 & 0.0 & 7.1 \\
\hline Fusarium solani & 1.3 & 1.5 & 9.0 & 7.6 & 14.9 & 3.4 & 5.8 & 3.2 & 1.2 \\
\hline Fusarium moniliforme & 5.2 & 18.5 & 13.6 & 9.8 & 5.4 & 14.6 & 7.0 & 6.4 & 10.7 \\
\hline Fusarium semitectum & 1.3 & 0.0 & 0.0 & 15.2 & 4.0 & 2.2 & 0.0 & 1.6 & 0.0 \\
\hline Fusarium nivale & 3.9 & 4.6 & 6.8 & 0.0 & 0.0 & 1.1 & 11.6 & 11.3 & 0.0 \\
\hline Fusarium oxysporum & 0.0 & 0.0 & 4.5 & 8.7 & 6.7 & 0.0 & 3.5 & 0.0 & 11.9 \\
\hline Penicillium spp. & 6.5 & 4.6 & 2.3 & 3.3 & 5.4 & 0.0 & 2.3 & 1.6 & 2.4 \\
\hline Trichoderma sp. & 5.2 & 0.0 & 0.0 & 1.1 & 12.2 & 0.0 & 4.6 & 0.0 & 9.5 \\
\hline
\end{tabular}

${ }^{a} \mathrm{~S}=$ Sample Number

Data shown in Table (3) indicate that the fungus Aspergillus flavus show the highest percentage of isolation frequency (14.2\%), followed by Apergillus niger and Apergillus ochraceus at 13.2 and $10.8 \%$, respectively. Whereas, the lowest percentage of isolation was noticed with the fungus Fusarium semitectum and Penicillium spp. at 2.7 and $3.2 \%$, respectively.

Table (3): Frequency (\%) of fungi isolated from nine Samples of wheat seeds cv. Sakha 69 on PDA medium.

\begin{tabular}{|l|c|}
\hline Fungus & $\begin{array}{c}\text { Mean Frequency } \\
(\%)\end{array}$ \\
\hline Aspergillus flavus & $14.2^{\text {a }}$ \\
\hline Apergillus niger & 13.2 \\
\hline Aspergillus ochraceus & 10.8 \\
\hline Aspergillus parasiticus & 7.4 \\
\hline Alternaria alternata. & 4.2 \\
\hline Stemphylium sp. & 4.6 \\
\hline Cladosporium sp. & 5.3 \\
\hline Drechslera sp. & 7.0 \\
\hline Fusarium solani & 5.3 \\
\hline Fusarium moniliforme & 10.2 \\
\hline Fusarium semitectum & 2.7 \\
\hline Fusarium nivale & 4.4 \\
\hline Fusarium oxysporum & 3.9 \\
\hline Penicillium spp. & 3.2 \\
\hline Trichoderma sp. & 3.6 \\
\hline
\end{tabular}

${ }^{a}$ Data recorded as mean (\%) of nine samples of wheat seeds cv. Sakha 69 on PDA medium for each isolated fungus.

Data presented in Table (4) show the effect of $9 F$. moniliforme, isolates on the percentage of preemergence and post-emergence damping-off of wheat seedlings, the investigated isolates show different significant levels of infections on wheat compared with control treatment. Isolate no. 1 of $F$. moniliforme from Sharkiya governorate showed the least infection percentage at both pre-emergence and post-emergence stages (7.5 and15\%, respectively) and the highest survival plants (77.5\%). Whereas, isolate no.5 from Dagahiliya showed highest percentage of infection at both pre-emergence and post-emergence damping-off stages of wheat at 32 and $42.5 \%$, respectively and the least survival plants at $25.5 \%$. The similar trend was recorded with isolate no.7 of Damietta, pre-emergence and post-emergence damping-off was 32 and 43.5\%, respectively and survivals $(24.5 \%)$. Regarding the other parameters of plant growth in relative to infection, there are a noticeable 
significant differences recorded in this respect i.e., isolate no. 1 and 8 from Sharkiya and Dagahiliya were the highest in plant height $(\mathrm{cm})$ and dry weight $(\mathrm{mg} / \mathrm{plant})$ and yielded 17.37 and $18.28 \mathrm{~cm} /$ plant height and gave 92.5 and 97.25 (mg/plant) of dry weight, respectively. The obtained results are somewhat similar to those reported by [4] and [5]. In their scientific work it was reported that the association and isolation frequencies of some fungal species isolated from wheat grains were significantly correlated with seedling variables and the significance of some variables may indicate the presence of causal relationship between wheat seed-borne fungi and the incidence of seedling diseases.

Table (4): Effect of nine $F$. moniliforme isolates on wheat cv. Sakha 69 in artificially infested soil under greenhouse conditions

\begin{tabular}{|c|l|c|c|c|c|c|}
\hline Isolate No. & $\begin{array}{c}\text { Geographic } \\
\text { origin }\end{array}$ & $\begin{array}{l}\text { Pre- } \\
\text { emergence } \\
\text { damping-off } \\
\mathbf{\%}\end{array}$ & $\begin{array}{l}\text { Post- } \\
\text { emergence } \\
\text { damping-off } \\
\mathbf{\%}\end{array}$ & $\begin{array}{c}\text { Survival } \\
(\mathbf{\%})\end{array}$ & $\begin{array}{c}\text { Plant height } \\
(\mathbf{c m})\end{array}$ & $\begin{array}{c}\text { Dry weight } \\
\mathbf{m g} / \mathbf{p l a n t s})\end{array}$ \\
\hline 1 & Sharkiya & 7.5 & 15 & 77.5 & 17.37 & 92.5 \\
\hline 2 & Gharbiya & 27.5 & 40 & 32.5 & 13.37 & 77.53 \\
\hline 3 & Kafr El-sheikh & 25 & 22 & 53 & 15.89 & 64.75 \\
\hline 4 & Behira & 20 & 25 & 55 & 15.43 & 67.75 \\
\hline 5 & Dagahiliya & 32 & 42.5 & 25.5 & 14.83 & 78.42 \\
\hline 6 & Behira & 15 & 27 & 58 & 15.57 & 69.75 \\
\hline 7 & Damietta & 32 & 43.5 & 24.5 & 13.45 & 74.00 \\
\hline 8 & Dagahiliya & 10 & 20 & 70 & 18.28 & 97.25 \\
\hline 9 & Qualyubiya & 30 & 39.5 & 30.5 & 14.82 & 80.25 \\
\hline 10 & Check & 5 & 0.0 & 95.0 & 20.42 & 119.5 \\
\hline L.S.D at $(\mathrm{P} \leq 0.05)$ & 9.95 & 15.0 & 13.42 & 0.83 & 10.68 \\
\hline L.S.D at $(\mathrm{P} \leq 0.01)$ & 13.44 & 20.26 & 18.12 & 1.12 & 14.43 \\
\hline
\end{tabular}

In the present study, wheat grains were planted in artificially infested soil with the investigated nine isolates of $F$. moniliforme under greenhouse conditions. Therefore, it seems reasonable to mention that the source of infection to wheat grains were only the $F$. moniliforme isolates which are the causal organism of seedling damping-off. The disease pressure during pre-emergence stage was higher than that during postemergence stage for all the tested $F$. moniliforme isolates. In addition; pre-mergence damping-off was positively correlated with infection (Table 5). These results imply that the role of seed-borne fungi of wheat as seedling disease incidents was more evident in the pre-emergence stage compared with the post-emergence stage. The occurrence and associations of $F$. moniliforme are of great importance in the ecology of host-pathogen interactions within such pathosystems, biotic and abiotic factors influence the distribution and abundance of pathogen species. Subsequently, patterns of association results from interrelationships among organisms and from environmental factors. These patterns depends on whether or not organisms select or avoid the same habitat, have mutual attraction or repulsion, or have no interaction and these results are in agreement with that results reported by [22] and [23].

Table (5): Correlation a among variables used in evaluating pathogencity of nine isolates of $F$. moniliforme from wheat grains.

\begin{tabular}{|c|c|c|c|c|}
\hline Variables & 2 & 3 & 4 & 5 \\
\hline 1- Pre-emergence damping-off $(\%)$ & $0.895 * * \mathbf{a}$ & $0.969 * *$ & $-0.835 * *$ & -0.515 \\
\hline 2-Post-emergence damping-off (\%) & & $-0.977 * *$ & $-0.844 * *$ & -0.274 \\
\hline 3-Survival (\%) & & & $0.863^{* *}$ & 0.396 \\
\hline 4-Plant height $(\mathrm{cm})$ & & & & 0.608 \\
\hline 5-Dry Weight (mg/plant) & & & & - \\
\hline
\end{tabular}

Phenogram in Fig.(1), using the average linkage cluster analysis between groups of nine $F$. moniliforme isolates relative to their pathogenicity on wheat cv. Sakha 69 show that the $F$. moniliforme, isolates were divided into two major groups, the first were four isolates of F5,F7,F2 and F9 and the second group were five isolates of $F$. moniliforme $(1,8,4,6$ and 3$)$. 


$\begin{array}{rrrr}5 & 10 & 15 & 20\end{array}$

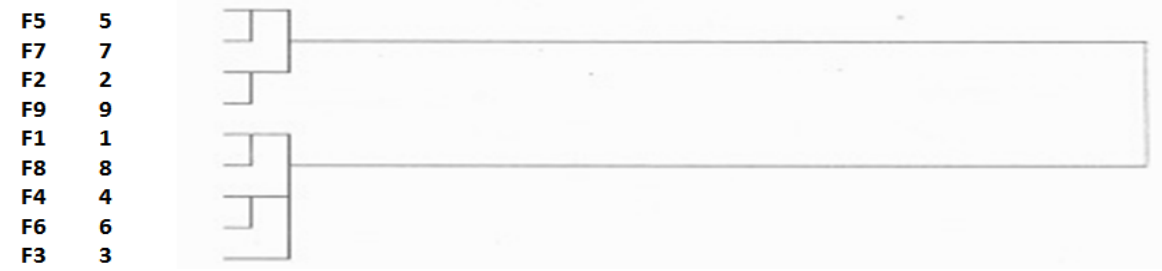

Fig (1): Phenogram using the average linkage cluster analysis between groups of nine Fusarium moniliforme isolates based on their pathogenicity (\%) on wheat seedlings.

For studying the molecular variations among the investigated $F$. moniliforme isolates; three different 10 mer random primers were used. The molecular variations among nine isolates in the present study were varied. The RAPD profile of amplification products generated with primers; shown in Fig. (2) primer-1 revealed a degree of similarities among the 9 tested $F$. moniliforme isolates. Primer-1 revealed that Fusarium isolates can be grouped into a number of sub clusters. Isolates no 2 and 9 in similarity up to $10 \%$, were grouped in one cluster and isolates no.3, 4 and 5 were grouped in another one cluster with similarity $15 \%$, and the last cluster grouped was isolates no.6, 8 and 7 in similarity $10 \%$, whereas, isolate no. 1 of Sharkiya were separated alone without any correlation with other isolates.

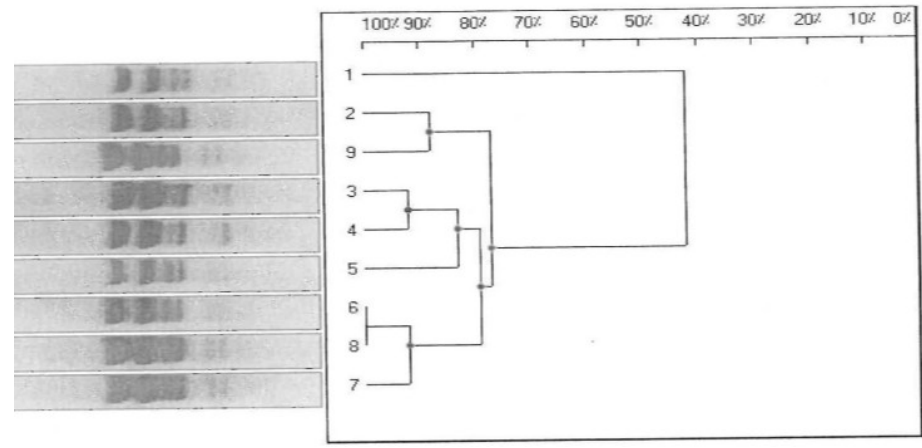

Fig. (2): Dendogram by UPGMA cluster analysis for DNA extracted from nine $F$. moniliforme isolates using RAPD (primer-1) .

The genetic variations among the nine isolates of $F$. moniliforme, by the RAPD profile of amplification products generated with primer-2; showed in Fig (3) primer-2 revealed a degree of similarities among the 9 tested F. moniliforme isolates. Primer-2 revealed that Fusarium isolates can be grouped into a number of sub clusters. Isolate no 1 and 3 are grouped in one cluster in similarity up to $10 \%$ and isolates no 2,6 and 9 were grouped in another cluster with similarity $15 \%$. Isolates no. 7, 8, 4 and 5 were grouped in one another subcluster of similarity up to $40 \%$.

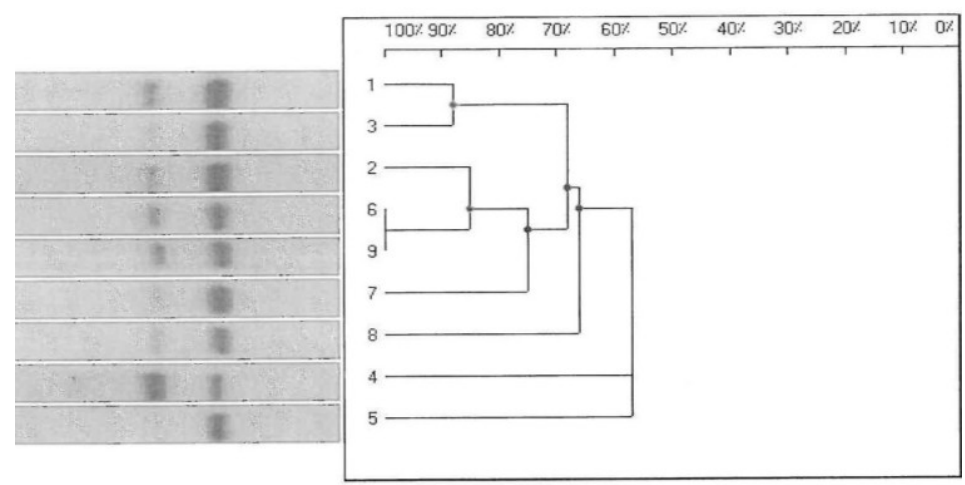

Fig. (3): Dendogram by UPGMA cluster analysis for DNA extracted from nine $F$. moniliforme isolates using RAPD (primer 2). 
The genetic variations among the nine isolates of $F$. moniliforme, by the RAPD profile of amplification products generated with primer-3 showed in Fig (4) primer-3 revealed a degree of similarities among the 9 tested $F$. moniliforme isolates it can concluded that isolates can be grouped into a number of sub clusters.

Isolates no. 1 and 8 are grouped in one cluster and isolate no. 5 and 7 were grouped in another cluster in similarity $70 \%$. Isolates no. 3 and 4 were grouped in another cluster in similarity up to $85 \%$, and isolates no. 2 and 9 were grouped in a single cluster in similarity 85\%.The dendogram in Fig.(4) show a high efficacy in grouping the investigated isolates and considered the best primer in this study.

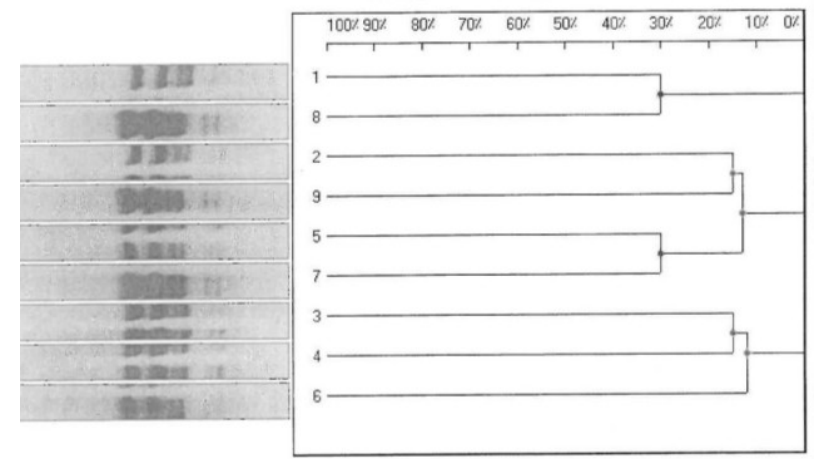

Fig. (4): Dendogram by UPGMA cluster analysis for DNA extracted from nine $F$. moniliforme isolates using RAPD (primer -3).

In the present study we have used RAPD-PCR technique to study the molecular diversity among nine $F$. moniliforme isolates relative to their pathogenicity and geographical distribution. DNA pattern from the isolates show that, there are a noticeable correlation among some isolates of $F$. moniliforme and the percentage of pathogenicity and grouped in one cluster i.e. isolate no.1 and 8 although they were from different governorates (Sharkiya and Dagahiliya). The primer-3 is different than the other primers in grouping the isolates and revealed the best grouping for the isolates i.e. isolates no. $1 \& 8$ grouped in one cluster and they were similar in their pathogenicity. Isolates no.5 \& 7 are grouped in one cluster and they were similar in their pathogenicity. This study provides a new insight to the concept on host-pathogen interactions. Also, gives an overview on the relationship between the pathogenicity of some important $F$. moniliforme isolates and the molecular diversity. [24] and [25]. Efficacy of primer-3 in grouping the tested isolates may be due to its ability to conjugate with different fragments of the extracted fungal DNA from nine $F$. moniliforme isolates. Differences in the pathogenicity of the investigated isolates in the present study depends on their virulence and the genetic structures, therefore a noticeable differences was shown in the percentages of infection against wheat seedlings; correlated sometimes with fungal phylogenetic characterization and these results were somewhat similar to that reported by [8] and [25].

\section{Conclusion}

Among various seed-borne mycoflora that affect seed health, the most important are the Fusarium spp. that not only affect seed germination, but also reduce seed vigor resulting in low yield. Thus, healthy seed plays an important role not only for successful cultivation but also for increasing yield of wheat crop. These pathogens may affect the plant resulting in a reduction of the grain quality. Random amplified polymorphic DNA (RAPD) is also a suitable technique to evaluate taxonomic identity. The application of (RAPD) to produce isolatespecific DNA-fingerprints is especially promising. This technique has the advantage of that no DNA base sequence information of the organism is needed. The technical simplicity and speed of RAPD methodology is a principal advantage over other techniques. Therefore, further studies must be directed towards this kind of work.

\section{References}

[1] Wiese MV (1984). Compendium of wheat diseases. $3^{\text {rd }}$ Ed. The American Phytopathological Society, pp. 106.

[2] Embaby EM, Nahed M Ayaat, Abd El-Hamid NH, Mona M Abdel-Galil, Yaseen AA, Marwa A Younos (2012). Detection of Fungi and Mycotoxin Affected Wheat Quality. J. Appl. Sci. Res., 8 (7): 3382-3392.

[3] Mathur SB, Olga Kongsdul (2003). Common Laboratory seed healthy testing methods for detecting Fungi, Danish Government Institute of Seed Pathology for Developing Countries Thorvaldsensvey57, DK- 1871. Frederiksberg C, Copenhagen, Denmark. pp. 399 .

[4] Mahmuda K, Yasmin N, Khanzada AK (1987). Effect of black point disease on the germination of wheat verities. Pak. J. Agric. Res., 8: 467-473.

[5] Kunwar IK (1989). Mycoflora associated with stored wheat and its milling fractions in India. Plant Sci., 99: $437-443$. 
[6] Armstrong GM, Armstrong JK (1981). Formae speciales and races of Fusarium oxysporum causing wilt diseases. pp. 391-399. In: Fusarium Diseases, Biology and Taxonomy. P.E. Nelson; T. A. Toussoun and R.J. Cook (eds.). Pennsylvania State University Press, University Park. pp.457.

[7] Gepts P (1993).The use of molecular and biochemical markers in crop evolution studies. pp. 51-94. In: (M.K.Hecht,ed.) Evolutionary Biology, Vol. 27. Plenum Press, New York.

[8] Williams JGK, Kubelik AR, Livak KJ, Rafaisik JA, Tingey SV (1990). DNA polymorphisms amplified by arbitrary primers are useful as genetic markers. Nucleic Acids Res., 18:6531-6535.

[9] Welsh B, Mc Clelland M (1990). Fingerprinting genomes using PCR with arbitrary primers. Nucleic Acid Res., 18:7213-7218.

[10] Nyvall RF (1981)."Field crops Disease Hand book". AVI Publishing Company, Inc., Westport, Connecticut, pp. 436.

[11] ISTA (1983). International Seed Testing Association, International Rules for Seed Testing. Seed Sci. and Technol., Supplement. .24 (1): 335 .

[12] Gilman JC (1966). "A Manual of soil Fungi", $2^{\text {nd }}$ Ed. The Iowa State Univ. Press, Iowa, pp. 450.

[13] Booth C (1971). "The Genus Fusarium". Commonwealth Mycological Institute, Kew, Surrey, England, pp. 237

[14] Barnet HL, Hunter BB (1979). "Illustrated Genera of Imperfect Fungi", $3^{\text {rd }}$ Ed. Burgess Publishing Company, Minneapolis, Minnesota, pp. 214

[15] Seem RC (1984). Disease incidence and disease severity relationships. Ann. Rev. Phytopathol., 22:133-150

[16] Bhutta AR, Hussain SA (1999). Seed-borne pathogens of wheat in Pakistan. Rachis, 18(2):66-68.

[17] Elvyra G, Audrone M, Albinas L, Jurate R (2006). The effect of environmental conditions on the variation of fungi and mycotoxin contents in oil flax seed. Ekologiya 3:64-70.

[18] Aly AA, Mansour MTM, El-Zefzaf HM (2008). Incidence and patterns of association of mycoflora from flax seed. J. Agric. Sci. Mansoura Univ., 33 (8) :5761-5770.

[19] Sulaiman E D , Husain SS (1984) Pathogenicity and effect of germination caused by Aspergillus and Penicillium species on wheat. Pak. J. of Sci. \& Ind. Res., 27: 359-362.

[20] Fakir GA (1999). Seed Health-an Indispensable Agro-technology for crop production. Lecture note for course on Agro-technology and Environment Management for the CARITAS officers at GTI, BAU, and Mymensingh from June 21-30, 1-4 pp.

[21] Hussein EM, Allam ADA, Aly AA, Amein AM, El-Samawaty AMA (2000). Separation by protein electrophoresis of Rhizoctonia spp. isolated from cotton seedlings. J. Agric. Sci. Mansoura Univ., 25:4035-4046.

[22] Singh DV (1983). Fungi associated with wheat seeds and their significance. Seed Res., 11:103-105. Ind. Res., 27: 359-362

[23] Sejiny MJ, Tawfik KA, EI-Shaieb MK (1984). Studies on mycoflora of cereal grains in the Southern West region of Saudi Arabia. Rev. Plant Pathol., 64: 2249.

[24] Gordon TR, Martyn D (1997). Population structure and the relationship between pathogenic and nonpathogenic strains of Fusarium oxysporum. Phytopathology, 87: 73-77.

[25] Liu Weicheng X, Jingtlui L, Hong Yu PH, Yu HH, Qiao GY, Lai Ronglin B (2002). RAPD analysis of isolates from Fusarium spp. Causing wheat head blight in Northeast China. Mycosystema, 21 (1): 63-70. 